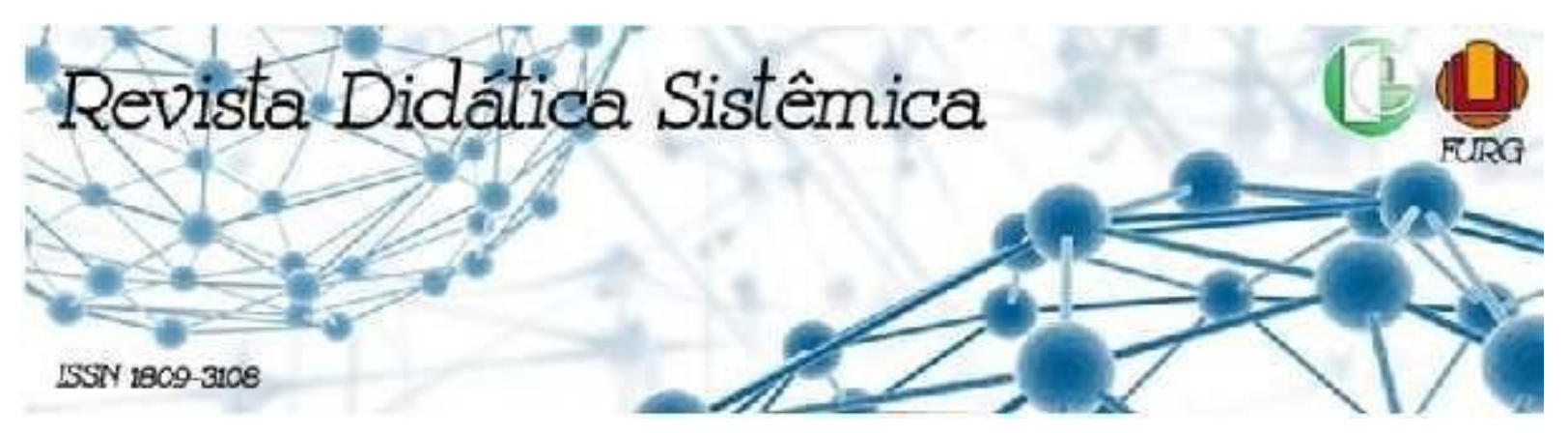

\title{
DIÁLOGOS COM O CANTAR-DANÇAR NA EDUCAÇÃO INFANTIL
}

\author{
Adriana Martins Correia ${ }^{1}$
}

\section{RESUMO}

Este texto, de caráter ensaístico, pretende colocar em cena o diálogo entre o universo dos brinquedos cantados e o trato com cantar-dançar na Educação Infantil. Parte da ideia de que o uso dessas manifestações traz em seu bojo uma lógica disciplinar, a partir das cantigas tradicionais e do brinquedo cantado pedagógico. Contudo, na contemporaneidade, este trato lida, também, com um outro produto que se cria a partir da midiatização, que incorpora e mantém velhos discursos, ao mesmo tempo em que os ressignifica a partir de novos sentidos e estéticas, dentro da flexibilidade própria da sociedade de controle. O trabalho é construído a partir da articulação entre a experiência da autora na docência, debates com docentes em formação inicial e continuada na Universidade, colocados em perspectiva com a literatura a respeito das relações entre escola e poder, da educação das infâncias e do ensino da dança na escola. Ao final, são apresentadas algumas propostas e experiências que buscam deslocar o cantar-dançar para fora dessa lógica prescritiva, vislumbrando a potência da criatividade das infâncias.

Palavras-chave: Educação Infantil; Dança; Brinquedos Cantados; Educação Física Escolar.

\section{DIALOGUES WITH SING-DANCING IN CHILDHOOD EDUCATION}

\begin{abstract}
This essay, of an essayistic nature, intends to stage the dialogue between the universe of sung toys and the treatment with singing-dancing in Early Childhood Education. It starts from the idea that the use of these manifestations brings a disciplinary logic based on the selection of traditional songs. At the same time, it deals with another product that exists from the media event, incorporates and maintains old discourses but reframes them from new senses and aesthetics within the flexibility of the control society. The work is constructed from the articulation between the author's experience in teaching, debates with teachers in initial and continuing education at the University, and the literature regarding the relationship between school and power, childhood education, and dance teaching in school. In the end, some proposals and experiences are presented that seek to move singing-dancing

${ }^{1}$ Universidade Federal Fluminense. Coordenadora do grupo de pesquisa Expressividades, performances andarilhas e espaços educativos (EXPANDE-UFF).

E-mail: adrianacorreia@id.uff.br
\end{abstract}


out of this prescriptive logic, envisioning the potency of childhood creativity.

Keywords: Early Childhood Education; Dance; Sung Toys; School Physical Education.

DIÁLOGOS CON EL CANTO-BAILE EN LA EDUCACIÓN INFANTIL

\section{RESUMEN}

Este ensayo, de carácter ensayístico, pretende poner en escena el diálogo entre el universo de los juguetes cantados y el tratamiento con el canto-baile en la Educación Infantil. Se parte de la idea de que el uso de estas manifestaciones trae consigo una lógica disciplinaria basada en la selección de canciones tradicionales. Al mismo tiempo que se trata de otro producto que existe del evento mediático, incorpora y mantiene discursos antiguos, pero replantearlos desde nuevos sentidos y estéticas, dentro de la flexibilidad de la sociedad de control. El trabajo se construye a partir de la articulación entre la experiencia del autor en la docencia, los debates con los docentes de la educación inicial y continua de la Universidad, puestos en perspectiva con la literatura sobre la relación entre escuela y poder, educación infantil y enseñanza de la danza en la escuela. Al final, se presentan algunas propuestas y experiencias que buscan sacar el canto-baile de esta lógica prescriptiva, vislumbrando la potencia de la creatividad infantil.

Palabras clave: Educación Infantil; Danza; Juguetes cantados; Educación Física Escolar.

\section{INTRODUÇÃO}

1978. A indústria fonográfica mundial vivia o apogeu da música Disco. No Brasil, a gravadora Copacabana lançava o LP Disco Baby. Na lista de músicas: pirulito que bate bate, marcha soldado, ciranda cirandinha, samba lelê, o cravo e a rosa, entre outras cantigas tradicionais infantis, todas elas tocadas em ritmo de "discoteque". A capa do álbum trazia dois bebês, um menino e uma menina, loiros, de olhos azuis. O LP era cantado pelo grupo "As melindrosas", formado por três jovens, entre as quais, uma, logo depois, se tornaria “Gretchen”, uma famosa cantora dos anos 80, que se notabilizou por sua música e dança sensuais. O alcance do grupo se massificou, apresentando a forma "disco" de dançar músicas infantis em programas de TV populares, estreando no Fantástico e visitando auditórios de apresentadores como Carlos Imperial, Chacrinha, entre outros.

2000. A gravadora Som Livre apresenta o primeiro produto da série "Xuxa só para baixinhos". Nos treze anos seguintes, seriam lançadas, anualmente, novas versões da série, inicialmente, em mídia de áudio e VHS e, posteriormente, em DVD. Nos diferentes volumes, o cardápio musical ía se alterando: versões músicas educativas infantis estadunidenses, seguidas por uma breve passagem pelo cancioneiro popular brasileiro, 
para, então, chegar em uma predominância de músicas compostas para a coletânea, por artistas nacionais. Muitas vezes, essas canções inéditas traziam lições explícitas: sobre o alfabeto, sobre o corpo e seu cuidado, sobre animais, entre outras. Em todas as versões do produto, as músicas tinham coreografias correspondentes, executadas por Xuxa Meneguel, acompanhada por crianças ou bonecos. Para além dessas mídias, o produto era, cotidianamente, exibido nos programas da apresentadora, transmitidos pela TV Globo durante as manhãs.

Primeira década dos anos 2000. A plataforma "YouTube" consolida-se como o domínio mais acessado para compartilhamento e acesso a vídeos. Criado para oportunizar a divulgação de vídeos "caseiros", rapidamente, se populariza e passa a mesclar a produção de amadores, artistas profissionais e pessoas que copiam e postam trechos de material da TV e do cinema. Nesse cenário, surgem os mais diversos vídeos musicais destinados ao público infantil, mas, talvez, o maior fenômeno da época tenha sido a série "A Galinha Pintadinha". Depois da viralização de um vídeo postado quase que acidentalmente, seus criadores passaram a investir em uma sequência de produtos da Galinha, mantendo, sempre, o mesmo formato: animações com figuras de animais e crianças, apresentando cenas interpretativas das tradicionais músicas infantis. A fórmula da "Galinha Pintadinha" passa a ser cada vez mais vista nesse canal: desenhos animados, usando, predominantemente, músicas de domínio público, livres de quaisquer impedimentos ou ônus relacionados aos direitos autorais.

Entre os últimos sucessos, está um produto da empresa sul-coreana Pinkfong, "Baby Shark", que conta a história de uma família de tubarões, hierarquicamente apresentada a partir do tamanho do filho, da mãe e do pai. A música é acompanhada com gestos que vão se ampliando, do uso de dedos, para as mãos e para os braços. Um menino, vestido de azul, apresenta o filho, o pai e o avô tubarões, enquanto, vestida de rosa, uma menina apresenta a mãe e a avó, tendo, ao fundo, a animação desses animais, também azuis ou rosas, de acordo com o sexo. Para além das marcas de gênero, os familiares idosos são apresentados no gestual a partir da característica de serem "desdentados". A origem da canção do Tubarão é controversa ${ }^{2}$ : algumas matérias jornalísticas atribuem a autoria a educadores

2 Segundo matéria divulgada pela Revista Veja, a canção foi composta, na década de 90 , por dois educadores norte-americanos. Já o site BBC News atribui a origem aos acampamentos de verão dos EUA na década de 1970, ou, ainda, que tenha sido inventada em 1975, em função do sucesso do filme Tubarão, de Steven Spielberg. https://vejasp.abril.com.br/blog/criancas-sao-paulo/baby-shark-verdadeira-historia/ 
estadunidenses; outras, dizem que era cantada como entretenimento em acampamentos religiosos para jovens nesse mesmo país.

Ao (re)apresentar esses episódios da cultura midiática destinada às infâncias, pretendo colocar em cena o diálogo entre esse universo e nossos fazeres, no que toca ao trabalho com o cantar-dançar na Educação Infantil. Parto da ideia de que, nesse processo, não há um simples uso do "brinquedo cantado" em que a mídia (televisiva, digital ou virtual) se resume a um mero suporte do conteúdo. Entendo que falamos de outro produto que existe a partir do acontecimento midiático, que incorpora e mantém alguns discursos das antigas canções, mas os ressignifica a partir de novos sentidos e estéticas.

O uso do termo "brinquedo cantado", para a discussão que apresento, comporta uma ampla gama de práticas. Falo, então, das manifestações da cultura popular, destacadamente, as cantigas de roda, parlendas, lengalengas e outras brincadeiras que misturam música e gestualidade e que têm como característica o desaparecimento da autoria original, sendo transmitidas geracionalmente. Falo, também, de manifestações que parecem advir do processo de escolarização das infâncias, em que passamos a assistir a uma "pedagogicização" das cantigas tradicionais, ou mesmo, a criação do "brinquedo cantado pedagógico", que surge para "ensinar" conceitos, valores e procedimentos para as crianças, através do uso lúdico da música e da dança. Apesar de não termos a origem precisa dessas canções, podemos suspeitar que "cabeça, ombro, joelho e pé" e "meus dedinhos", provavelmente, tenham nascido como atividades já criadas na ou para a escola.

Podemos, ainda, perceber que outros espaços de socialização infantil atuam como ambientes de criação e de ressonância de brinquedos que combinam canções com gestualidade. É notória a presença dessas práticas em animações de festas e de espaços de lazer, bem como em encontros religiosos, destacadamente, aqueles relacionados ao protestantismo e, mais tardiamente, aos ramos carismáticos da igreja católica.

Independentemente da origem do brinquedo cantado, interessa-me problematizá-lo, considerando (também) sua existência como cultura midiática que dialoga com a escola, presente como ferramenta, conteúdo ou como pano de fundo em eventos e rotinas da Educação Infantil.

Esse texto, de caráter ensaístico, é construído a partir da articulação entre a literatura, a minha experiência da docência, nessa etapa da escolaridade e, principalmente, os debates 
com docentes em formação inicial ${ }^{3}$ e em ações de formação continuada, das quais participei como coordenadora ${ }^{4}$.

Algumas questões são o ponto de partida para as discussões aqui apresentadas. Quais são os sentidos e os desdobramentos pedagógicos que se estabelecem quando trazemos o cantar-dançar para a escola através do brinquedo cantado? Que concepções de sociedade, de corpo e de infância incorporamos a partir do consumo da versão espetacularizada das canções infantis, via gravações de apresentadoras infantis ou animações da internet? Quais aspectos morais e estéticos estão incutidos nessas práticas, considerando suas relações com religiosidade e marcas de gênero e etnicidade?

A partir destas questões, traço um percurso que se detém em alguns temas. O primeiro se refere às relações entre música, disciplinarização e controle, considerando as lições contidas nas letras e os comportamentos por elas sugeridos. O segundo tema se refere aos dispositivos de infantilidade que forjam, através do cantar-dançar, formas de ser criança fortemente definidas por marcadores étnico-raciais, de gênero, além de se aproximar, muitas vezes, de aspectos normativos relacionados à religiosidade. Por fim, aproximo a discussão dessas práticas do universo dos corpos que dançam, pensando como a prática pedagógica na Educação Infantil, e, em particular, na Educação Física, pode se circunscrever ao gesto estereotipado ou pode se ampliar como forma de criação e de performatividade resistente.

\section{CRIANÇA EDUCADA, É ASSIM QUE FAZ}

Não é novidade o fato de que, em diferentes culturas, há todo um aparato cultural que se organiza no sentido de regular a vida das infâncias. Assim como as lendas, fábulas e os contos de fada, as músicas que se dirigem às crianças trazem lições, avisos e recomendações para que as mesmas assumam determinados comportamentos, seguindo preceitos morais e religiosos. Bem antes das mídias eletrônicas, a antiga canção já nos alertava: se não marchar direito, vai preso pro quartel!

3 Refiro-me às experiências com discentes da disciplina PPE I (Pesquisa e Prática de Ensino na Educação Física, na Educação Infantil), no Curso de Licenciatura em Educação Física, da Universidade Federal Fluminense, além de considerar como parte de tais experiências as importantes interlocuções com as docentes das escolas em que atuo como supervisora de PPE.

4 Refiro-me aos cursos desenvolvidos na Universidade Federal Fluminense, pelo Laboratório de Educação das Infâncias e Cultura Corporal, nos anos de 2018 e 2019, com professoras de Educação Infantil da rede municipal de Niterói. 
Para além do tema aqui tratado, há questões sobre as quais podemos refletir quando se fala nos processos disciplinares e de controle que envolvem a Educação Infantil, entendendo que tais processos são distintos, mas que convivem no espaço escolar contemporâneo, alternando-se, contrapondo-se e, até mesmo, acontecendo em relação de complementaridade.

Foucault (1987) nos fala dos dispositivos de disciplinarização quando, em Vigiar e Punir, coloca em perspectiva a escola, a caserna, o hospital e a prisão. O poder disciplinar, mais característico dos "colégios" para as crianças mais velhas, chega, também, a atingir o processo de escolarização da pequena infância, através de procedimentos que buscam economia e eficácia dos movimentos, não sob a coerção violenta, mas sim a partir de operações minuciosas que resultam em corpos exercitados e, portanto, dóceis. As rotinas e arquiteturas panotípicas se alinham a regimes disciplinares que "têm como fim principal um aumento do domínio de cada um sobre seu próprio corpo" (FOUCAULT 1987, p.164), através do cumprimento de um script de ações que são, inicialmente ordenadas, até que estejam plenamente incorporadas.

Olhando para a experiência cotidiana, na prática de ensino, e dialogando com docentes em formação continuada, é possível perceber que a forma disciplinar ainda ganha contornos evidentes em muitos espaços na Educação Infantil. Não é raro ver, mesmo em escolas que se enunciam como não tradicionais, mecanismos como o deslocamento em filas, o uso da roda mais como forma de imobilização do que de interação, o esquadrinhamento rígido dos tempos de cada atividade na rotina cotidiana. Mais recentemente, aparatos tecnológicos, como câmeras nas salas de aula, têm acentuado os processos de vigilância do trabalho docente nas escolas privadas, muitas vezes, sob o argumento da segurança, que visa atrair os/as clientes que matriculam seus filhos e filhas

De forma disciplinar, as canções têm entrado na escola não apenas para ameaçar quem não "marcha direito", mas também para condecorar quem sabe como se deve andar, como ensinam as músicas da hora de formar fila: "quem vai chegando, vai ficando atrás, criança educada é assim que faz", ou "um atrás do outro, igual a gafanhoto".

Ao serem consumidas em suas versões midiatizadas, as canções infantis podem sofrer uma exacerbação desses mecanismos disciplinares, através da ressonância do dispositivo audiovisual. Na versão da animação Galinha Pintadinha ${ }^{5}$, a marcha do soldado

5 Disponível em https://www.youtube.com/watch?v=8Dwr0wgrt0E 
começa por uma brincadeira de dobradura de chapéu de jornal; logo depois, um menino (mais alto e branco) lidera a marcha, puxando a fila, seguido por uma menina, um menino oriental e mais uma menina, todos de altura decrescente na fila. Em seguida, estão alinhados lado a lado, com o punho sobre o peito, com o hino nacional entrando como música incidental. A bandeira nacional, em foco, sendo balançada, encerra a animação.

O vídeo tem mais de dez anos de publicação. Sem dúvida, já portava elementos de uma determinada simbologia de civismo e de imagens de crianças ocupando distintas posições hierárquicas. Pensando no momento social e político de avanço conservador que vivemos, no Brasil, nos últimos anos, cabe indagar: quais são os sentidos que podem advir do uso deste material na escola, desde sua existência como "conteúdo selecionado" para uma aula, até as apropriações que as crianças poderão fazer ao assistir, cantar e brincar com tal material?

Certamente (e felizmente), não caberá uma única resposta a essa pergunta, mas entendo que, potencialmente, a espetacularização do audiovisual é um veículo de facilitação para os mecanismos de docilização, no sentido de incluir as infâncias dentro de uma ideia de povo-nação ${ }^{6}$. A escola que forja a criança para ser povo, caminha no sentido da produção de homogeneidades, não comporta a diferença, portanto reproduz ciclicamente a desigualdade.

O fato de o poder disciplinar ainda ocupar um lugar de destaque na educação das infâncias, evidencia um contrassenso se pensarmos nas abordagens teórico-metodológicas que fundam o pensamento pedagógico para essa fase, notadamente, aquelas surgidas a partir do século XX. Mesmo considerando as diferenças de toda ordem, esses autores e autoras trazem, para a cena da escola, questões como a centralidade de quem aprende, as demandas a partir dos interesses e o foco no processo subjetivo de fazer e saber, considerando as diferenças dos tempos e formas de aprendizagem.

Nesse ponto, buscando dialogar com Veiga-Neto (2008;2021), podemos perceber que a educação escolar, embora ainda fortemente disciplinadora, desloca sua ênfase do poder disciplinar para a ênfase no controle, ganhando contornos que merecem atenção, a partir da apropriação dessas concepções pedagógicas por um certo pensamento anarcoliberal ${ }^{7}$. A escola "aberta", "ativa", "não diretiva", que pretende colocar em xeque o 
poder disciplinar, também se abre às possibilidades do exercício do controle, que aposta em um sujeito "flexível", que deve aprender a se autogerir diante das descontinuidades, assumir escolhas, avaliá-las. Nessa captura, o modus operandi anarcoliberal se infiltra na escola através de "modismos de certas formas de aprendizagem, do autoempresariamento, da cega obediência à teoria do capital humano e seu endeusamento, da educação domiciliar integral, da celebração da educação a distância” (VEIGA-NETO, 2021, p.262).

Voltando ao tema central deste texto, entendo que a música e o brinquedo cantado são atravessados pelas redes de controle, às vezes, com mais ênfase nestas do que nos mecanismos disciplinares. A ação do trabalho docente, ao buscar apoio na mídia audiovisual, pode ser, justamente, ser uma expressão disso. Como destacam Abramowicz, Levcovitz e Rodrigues (2009), na sociedade de controle, diferente do mundo disciplinar, não há um dentro e fora do trabalho, não há um desligamento das redes. Docentes e discentes, assim como aulas e currículos, não se circunscrevem aos limites temporais e espaciais da escola.

Nesse caso, professoras e professores se veem diante do desafio da fluidez, do clamor pela "inovação", da ideia de que o currículo é flexível e que deve dialogar com as culturas infantis que extrapolam os muros da escola. Nada mais óbvio, então, que seguir as crianças em suas navegações pelas redes, ao mesmo tempo em que mostram para essas crianças novos "achados infantis" nessas plataformas. Nesse processo, o argumento do "resgate" da cultura popular tradicional, através das regravações das cantigas tradicionais, parece, também, ser um fortíssimo motivo para se consumir esses produtos na escola.

Faço, aqui, uma inflexão diante dessa ideia de que o poder exercido pelo controle opera, cada vez mais, em torno do trabalho docente. Mas o que acontece a partir de então? Da mesma forma que perguntamos sobre o que as crianças fazem ao receber as músicas e vídeos "disciplinadores", podemos indagar a respeito dos múltiplos acontecimentos, achados, percursos e diálogos que envolvem educadores e educadoras ao se aventurarem pelo universo audiovisual e ao trazê-lo para dentro de suas aulas. Parar para perguntar, talvez, seja uma forma de colocar em questão a fórmula vazia da "docência flexível”, que responde às demandas do controle para investir nas possibilidades consistentes de uma docência investigadora e reflexiva, ao lidar com práticas relacionadas à música e à expressividade na contemporaneidade.

sociedade do controle, responsabilizando o sujeito por suas "escolhas", justificando as relações de precarização do trabalho e suas consequências. 


\section{TODO MUNDO TÁ FELIZ, TODO MUNDO QUER DANÇAR}

Os usos disciplinares e os mecanismos de controle que acompanham o cantar-dançar, na escola, guardam relação com a construção de imagens de infância que vão sendo propostas pelos modelos de escolarização. Em relação aos aspectos disciplinares, as práticas rítmicas e expressivas têm sido uma ferramenta privilegiada para colocar em ação o que Corazza (2002) chama de dispositivos de infantilidade. Trata-se de um mecanismo que aposta na precariedade da criança, a torna um ser dependente, que demanda instrumentos disciplinadores específicos que possam, então, encaixá-la futuramente no mundo adulto. Músicas, como as citadas acima, cumprem, ludicamente, esse papel.

Essa é uma das formas de inserir a criança no contrato social, de modo que as infâncias venham se constituir como povo. Porém, para além dos enquadramentos disciplinares relacionados à ordem e à austeridade, há toda uma forma de existir para que uma criança componha essa ideia. O primado da socialização, como algo que forja o cidadão, é uma delas. Dessa forma, “(...) as iniciativas pedagógicas calcadas no gregarismo assujeitam e subjetivam a criança pela uniformização de seus desejos, pela pasteurização de suas singularidades, pelo apassivamento de seus talentos e pela desautorização de seu discurso" (ABRAMOWICZ; LEVCOVITZ; RODRIGUES, 2009, p.187).

Nesse sentido, acrescento que o cantar-dançar tem sido associado não só à questão da socialização, como também à ideia de que há uma relação direta e necessária entre infância e alegria. Podemos traçar uma linha que vai desde clássicos do cancioneiro escolar até os "hits" da música comercial contemporânea, seja infantil ou não. Em um debate durante um encontro de formação continuada, reunindo um grupo de professoras com idade entre 29 e 56 anos, elencamos uma série de canções que habitam aulas e festas e que poderíamos considerar como "clássicas" no repertório escolar. Depois de termos destacado tais canções, fomos avaliando haver um traço em comum a respeito da "criança sempre feliz" em um determinado grupo de músicas, assim como, em seguida, descobrimos outras famílias de modalidades e usos de canções recorrentes nos diferentes momentos do cotidiano escolar. Sobre a alegria, a mais antiga lembrada foi:

Criança feliz, feliz a cantar

Alegre a embalar, seu sonho infantil

Oh, meu bom Jesus, que a todos conduz 
Olhai as crianças do nosso Brasil ${ }^{8}$

Em seguida, boa parte dessas professoras disse ter sido, quando criança, "baixinha da Xuxa"9. A partir dessa influência, mencionaram músicas comuns em festejos na escola, que, por vezes, ainda são utilizadas em apresentações, como Ilariê e Tindolelê, cujo refrão dá o título a essa seção. Uma delas lembrou que, dentro desse espírito, uma das músicas que costumam frequentar a escola é "Festa", popularizada pela cantora Ivete Sangalo, que não se destina, especificamente, ao público infantil. Assim, vemos que essa ideia de uma infância idealmente feliz, manifesta no cantar-dançar, foi algo identificado naquele grupo, composto por professoras de diferentes gerações.

Vimos, ainda, que essa felicidade se une a outros aspectos de determinadas imagens de infância. No caso da primeira canção, a criança feliz é guiada e protegida a partir da sua condição de pessoa cristã. Enquanto falávamos dessa música, uma professora lembrou de um vídeo da dupla de palhaços-cantores "Patati-Patatá", que faz parte de uma coletânea recente e muito usada nas escolas. Nessa faixa, os cantores cantam, em sequência, um sucesso do Palhaço Carequinha, na década de 1950, chamado "O bom menino" e a música “Como vai, vai, vai...”, também lançada por um palhaço, Arrelia, alguns anos antes ${ }^{10}$.

Na versão de Patati Patata ${ }^{11}$, o bom menino é representado por um garoto branco, vestido em trajes dos anos 50 (calça curta, suspensórios, gravata borboleta e cabelo engomado), mostrado como exemplar, por uma criança que não faz xixi na cama nem malcriação, que vai sempre à escola, que sabe toda a lição. Além disso, obedece à mãe e, por isso, "papai do céu" protege o bom menino. Essa proteção é ilustrada por um feixe de luz vindo do céu, como em filmes bíblicos, que, em seguida, materializam uma grande mão branca que abençoa a cabeça da criança. A finalização do vídeo, com a música "como vai, vai, vai...", continua apresentando as crianças em trajes cinquentistas (todas elas brancas), respondendo com a parte da letra que "vão bem, bem, bem...".

8 Canção da Criança de 1952, de Francisco Alves e René Bittencourt. Foi regravada por grupos e artistas como o Palhaço Carequinha, Turma do Balão Mágico, Patotinha, além de estar presente em vídeos animados no Youtube. Fonte: https://www.marcelobonavides.com/2011/10/cancao-da-crianca-1952.html, acesso em $12 / 04 / 2021$.

9 A apresentadora Xuxa Meneguel, "Rainha dos Baixinhos", comandou por 30 anos programas infantis na TV Globo e em emissoras internacionais. Os últimos 10 anos de programa estavam relacionados com uma produção para o consumo de crianças mais novas, nas coletâneas "Xuxa só para baixinhos".

10 Arrelia e Carequinha foram dois palhaços que se popularizaram, sendo apresentadores de programas infantis na TV brasileira, respectivamente nas décadas de 50 e 60.

11 Disponível em https://www.youtube.com/watch?v=rk_PovR6XYw 
Ao debatermos sobre isso, algumas professoras declararam que, se fossem fazer uma seleção para uma atividade ou evento, avaliariam que o conteúdo dessas músicas não teria sentido para o trabalho pedagógico, mas que, como música/vídeo "de fundo" ou de passatempo, já utilizaram ou poderiam utilizar o link ou DVD do "bom menino".

A questão da branquitude predominante, nos vídeos, foi algo identificado por algumas docentes, que afirmaram que, hoje, ao avaliar esse tipo de material, costumam observar isso criticamente. Em pelo menos um caso, tivemos o relato de uma professora que afirmou sempre buscar vídeos com maior representatividade étnico-racial, destacadamente, em relação às crianças negras.

Partimos, então, para analisar a produção virtual musical contemporânea. Algumas professoras apontaram para o fato de que, atualmente, algumas produções populares têm buscado incluir personagens não brancos e citaram a turma do "Mundo Bita", em que as três crianças da animação são representadas por um menino ruivo, um menino negro e uma menina loira. Assim, percebemos que a produção atual tem dialogado no sentido de atender, ainda que por fins comerciais, às demandas do discurso da diversidade.

Isso não quer dizer, necessariamente, que haja um processo efetivo de compromisso com trato com as diferenças. Na canção que Bita (personagem principal, dono do circo), vai para a África. A narrativa é impregnada de marcas do racismo estrutural. Na animação, aparecem animais coloridos, e os seres humanos são os viajantes, Bita e um palhaço branco. A única referência de "humanidade" do continente é dada por três figuras, compostas por máscaras africanas gigantes, sem tronco e quadril, e com braços e pernas em tom marrom, que "dançam" sugerindo o que seria uma gestualidade daquele lugar.

São de longa data as marcas que produzem o silenciamento das desigualdades e das opressões. Vasconcellos (2008) nos narra uma dessas, em que uma sinhazinha é substituída por uma barata.

Um dos brinquedos cantados da nossa tradição dizia: "Sianinha diz que tem / sete saias de balão / E mentira, ela não tem / nem dinheiro pro sabão. / Ra, ra, ra, / Ra, ra, ra,/ Nem dinheiro pro sabão" (...) e Sinhaninha vai sendo ridicularizada por suas mentiras que buscam esconder sua penúria. O processo de "assepsia pedagógica" varreu pra longe a Sinhaninha, pois não e educado rir de uma pessoa apenas porque ela não tem dinheiro nem para sabão, que dirá para as ricas roupas de Sinhaninha. (...)E, assim, perde-se uma grande oportunidade de discutir em sala de aula o que eram Sinhazinhas? Quando existiram? Como viviam? Como se vestiam? Quantos escravos tinham? 


\section{AGORA NINGUÉM PODE SE MEXER... ESTÁTUA! (?)}

As cantigas e suas letras revelam um aparato discursivo disciplinador, mas que, no caso dos brinquedos cantados, não costumam vir sozinhas. Quando me detive em descrever as cenas dos vídeos acima, foi porque entendo que dialogam, empaticamente, com os corpos infantis. Esse processo afeta as crianças que vivem corporalmente essas imagens, o que torna, particularmente, sensíveis questões como a da representatividade, por exemplo.

Para além disso, mesmo antes das mídias eletrônicas, o brinquedo cantado sugere e, até mesmo, prescreve formas de se mover a partir das histórias que contam. Nas cantigas populares tradicionais, muitas vezes, as letras não apresentam narrativas claras e a gestualidade que costuma acompanhá-la não, necessariamente, faz uma tradução literal da letra. Por exemplo: na lenga-lenga "pirulito que bate-bate", apesar da correspondência com as batidas de mão, a letra em si não explica o que o doce tem a ver com a batida, nem há qualquer gestualidade que "narre" o pirulito nas diferentes formas que conhecemos da brincadeira.

Já o brinquedo cantado pedagógico costuma buscar uma literalidade ou correspondência do gesto em relação à letra, tendo uma ação prescritiva em relação à resposta, ou seja, o corpo executa o que a música manda. A partir disso, algumas implicações podem ser discutidas.

A primeira delas é a diferença entre os possíveis sentidos pedagógicos que propomos ao trabalharmos com uma ou outra forma. Buscar modos de se dançar as cantigas tradicionais coloca nossas crianças em contato com histórias de outras gerações, permite a pesquisa do repertório com as pessoas mais velhas, que poderão apresentar formas diferentes de fazer e, até mesmo, variações nas letras. Traz, também, discussões interessantes para a sala de aula. Certa vez, um aluno me contou que seu avô disse não conhecer nenhuma cantiga de roda, por ser uma brincadeira para meninas.

Já cantigas pedagógicas apresentam outras questões. Começo pelas músicas normalmente cantadas nas "rodinhas", relacionadas à rotina diária ou que contam historinhas. Podemos citar a dança em que as crianças sentadas fazem a mímica da janelinha que fecha quando está chovendo, e abre se o sol está aparecendo, movimentando apenas os punhos. Na música do Pintinho Amarelinho, as crianças, também, concentram seus movimentos nas mãos e braços, fazendo o bico do pintinho, representando sua patinha ciscando na mão, suas 
asas batendo ou imitando o gavião. Gaviões feitos a partir de polegares cruzados, trombas de elefante que surgem de um braço passando pelo nariz, orelhas de coelhinhos feitas por mãozinhas na cabeça são, entre outros, exemplos clássicos do gestual estereotipado do cantar-dançar na escola. Esse gestual prima pela imobilidade do resto do corpo e pela limitação do seu deslocamento pelo espaço.

Por outro lado, muitos deles trabalham de forma análoga a de um jogo de desafio de habilidades. "Cabeça, ombro, joelho e pé" - começa com uma identificação simples das partes do corpo, para, em seguida, refinar os acertos em olhos, boca, orelhas e nariz. E por aí vai uma infinidade de músicas que geram desafios de identificação e de movimentação das diferentes partes do corpo. Há, ainda, as lenga-lengas e danças que se complexificam pelas dificuldades de coordenação, de lateralidade, pelas variações de espaço e velocidade.

Mas porque isso deveria ser colocado em questão? Antes de tudo, cabe dizer que não se trata de avaliá-las como "ruins" ou "erradas", mas entendo que, do ponto de vista da expressividade, cerne do cantar-dançar, essas práticas são precárias ou são de outra ordem.

A precariedade contida nos gestos estereotipados se dá primeiro em função da imobilidade que a abordagem dessas práticas, normalmente, gera: muitas vezes, as crianças estão sentadas, fazendo de seus braços e mãos fantoches de interpretação literal das músicas ${ }^{12}$.

Outra questão diz respeito ao movimento pronto, aprendido por imitação. Nas práticas de ensino com estudantes de Educação Física, temos colocado em questão o porquê de se demonstrar essas mímicas às crianças, para a interpretação de músicas ou brincadeiras de representação de animais, em vez de sugerir que apresentem suas próprias criações. Se entendemos que esse é um momento de experiência da arte, podemos nos inspirar em Deleuze (2006) quando apresenta o seu texto sobre "O que as crianças dizem", associando seus modos de falar ao próprio caráter indeterminado da arte.

(...) o indefinido não carece de nada, sobretudo de determinação. Ele é determinação do devir, sua potência própria, a potência de um impessoal não é uma generalidade, mas uma singularidade no mais alto grau: por exemplo, ninguém imita $o$ cavalo, assim como não se imita tal cavalo, mas tornamo-nos um cavalo, atingindo uma zona de vizinhança em que já não podemos distinguirmo-nos daquilo que nos tornamos. (DELEUZE, 2006, p.77-78).

12 Pensando o sentido transdisciplinar da Educação Física nessa etapa, temos debatido como esse campo de conhecimento poderia estabelecer um diálogo profícuo com outros que circulam na Educação Infantil, no sentido de se pensar nas possibilidades de uma exploração mais ampla das possibilidades corporais 
Em relação aos brinquedos cantados que envolvem habilidades e desafios, entendo se tratar de uma prática que investe em ações de uma outra ordem, bem mais próximas ao jogo do que à dança. Cabe dizer que não entendo "dança" e "jogo" como entidades estanques, de fronteiras rígidas, mas que, do ponto de vista da ação pedagógica, a diferença terminológica faz sentido como algo que proporciona experiências distintas.

No caso da dança, a distinção não a faz melhor ou pior que o jogo, mas coloca a expressividade em cena, como sentido principal da atividade. Para ilustrar isso, costumo discutir com docentes em formação o porquê de uma "corrida dos animais" nunca dar certo. Que criança inteligente, querendo ganhar uma corrida, iria manter-se como um coelho pulando em dois pés juntos? No meio da brincadeira, quem escolheu ser coelho transmutase em guepardo.

Os brinquedos que não envolvem competições, mas também exigem "acertos" de habilidade, da mesma forma, afastam-se da centralidade da experiência expressiva. Danças que pedem rápidas respostas do tipo "pracima-prabaixo-prumlado-prooutro" são divertidas e trazem desafios em relação à coordenação, assim como as máquinas de dança dos parques. Sem entrar na discussão do sentido dessas práticas na escola, o que advogo, aqui, é que as mesmas não ocupem o espaço da experiência da expressividade e do movimento criativo em nossas aulas.

Assim, pensando nos possíveis caminhos para esse trato com o movimento autoral, é preciso, antes de tudo, acreditar que as crianças pequenas são capazes de criar dança. É preciso aceitar que não farão isso sentadas em rodinhas, mas se dispersarão pelo espaço, intercalarão momentos de participação com contemplação.

\section{UM PERCURSO DE IMPROVISOS E COMPOSIÇÕES}

Apresentadas essas reflexões e experiências, coloco, aqui, algumas perspectivas que vislumbro em função do percurso pelo qual me movo, aprendendo com as crianças na escola, com docentes em formação e com colegas da Educação Básica que têm sido parceiras de trabalho, compartilhando a riqueza de suas vivências.

Buscando escapar à lógica disciplinar, são necessários caminhos que possam se contrapor aos dispositivos de normalização (de gênero, étnico-racial, religiosos, entre outros), ao mesmo tempo em que promovam a desconstrução das estereotipias do gesto que daí advém, já que letras e movimentos são, ao mesmo tempo, forma e conteúdo. 
Vejo linhas de fuga nas vivências estéticas que surgem a partir da inclusão do estudo das relações étnico-raciais na educação brasileira. Quando a escola se abre, de fato, para a inclusão das manifestações expressivas, como as afrodiaspóricas ou indígenas em seu currículo, ela contribui para a desconstrução dos dispositivos de normalização. Ao mesmo tempo, apresenta e valoriza outros saberes, outras formas para se gostar, no sentido que propõe Agamben, no qual o gosto se traduz como uma superação da fratura entre conhecimento e prazer, quando se dá no encontro com o belo (AGAMBEN, 2017, p.78).

Entendo ser este um dos caminhos expressivos que as crianças podem encontrar fora do gesto estereotipado. Isso se dá não apenas pelo fato de que o samba de roda, o jongo, os cocos trazem novos repertórios, novas belezas e formas de lidar com o corpo e o ritmo. Há, também, nessas danças, a abertura à dinâmica não coreografada, a uma liberdade maior na exploração das movimentações básicas, que, muitas vezes, não se relacionam a letras ou, ainda, que as tenha, costumam trabalhar de forma menos amarrada a uma interpretação literal, mais característica das manifestações ocidentais de origem europeia.

No entanto, para além dos repertórios, (sejam populares, eruditos, de massa), há formas de abordar o trato com a dança que tem sido negligenciada na escola, notadamente, na Educação Infantil. Falo de caminhos que sejam alternativos ao ensino dos repertórios prontos e que, ao mesmo tempo, fujam dos pressupostos essencialistas de algumas vertentes da "dança criativa" que se forjaram no século $X^{13}$. Concordando com Brasileiro $(2003){ }^{14}$, acredito que temos, na improvisação e na composição, duas importantes possibilidades, no sentido de que as crianças possam fruir da arte e se perceber como agentes que experimentam, mas também reelaboram as práticas culturais.

A valorização da improvisação coloca em destaque o gesto que surge a partir do encontro do sujeito com um acontecimento que o instigue a dançar: uma música, um ruído, uma imagem, um objeto, um sentimento. É importante destacar que o improviso não vem de um extravasamento natural de um "eu essencial", mas sim do encontro entre as experiências

13 Refiro-me a algumas abordagens inspiradas na Dança Moderna, e, em especial, a algumas que se desenvolvem a partir do sistema proposto por Rudolf Laban. A despeito da enorme contribuição dessas vertentes, algumas leituras têm entendido a dança moderna e o Sistema Laban como formas que desvelam a "natureza" do movimento humano, sem considerar seu aspecto historicamente datado e situado a partir de uma epistemologia eurocêntrica. Para mais detalhes sobre essa crítica, ver Marques (1999).

14 Como defende essa autora, há que se valorizar “(...) a necessidade de conhecer um universo mais amplo de referências sobre a dança e seus diferentes repertórios, bem como as possibilidades de improvisação e reconstrução coreográfica dos repertórios já construídos” (BRASILEIRO, 2003, p.54). 
de quem dança com um acontecimento daquele momento. $\mathrm{O}$ improviso é sempre inédito, singular, fugaz, existe em diálogo com cultura e com as condições de cada tempo e espaço. Daí, a importância do trabalho docente, que não interfere no momento dessa criação, mas está longe de ser neutro, pois cria ambiência quando propõe (ou não) tema e seleciona elementos para o processo criativo das crianças.

Quando falo dessa não neutralidade, entendo que a intencionalidade não se dá no sentido de esperar resultados, e sim no sentido da ampliação de possibilidades. Por exemplo, apresentar músicas de matrizes étnicas que vêm sendo silenciadas não significa garantir, objetivamente, a valorização dessas culturas, mas viabiliza a experiência em um universo repleto de diferenças, abrindo caminhos sensíveis para a desestabilização das estéticas normativas.

Assim, cabe (e urge) promover o acesso às diversas culturas populares. Cabe explorar paisagens sonoras desconhecidas pelas crianças, além de estimulá-las a criar a partir de outros sentidos, incluindo histórias, imagens, objetos e outros corpos. Cabe, também, saber por que esses elementos foram selecionados para aquele contexto.

A dança, também, se cria por composição, por um processo que alterna a improvisação com a organização mais racional do gesto criado ou selecionado em um repertório já conhecido, formando textos. Falando assim, parece algo complexo para a Educação Infantil, mas muitas experiências têm mostrado como as crianças pequenas são capazes de compor suas danças, individualmente ou em grupo.

Um dos caminhos que temos explorado é, justamente, a recriação desses brinquedos cantados prescritivos: brincar de fazer "o que a música manda", com gestos diferentes dos habituais e que se ampliam por todo o corpo; brincar de dançar "ao contrário da música"; refazer a letra para explorar outros gestos; esses são alguns exemplos que tenho visto acontecer. O mesmo temos feito com as músicas massificadas, quando as crianças as trazem para a escola, seja simplesmente criando um novo gestual e gerando uma composição original daquele grupo.

Assim, as turmas da Educação Infantil têm mostrado ser possível compor coletivamente, fugindo do tradicional processo de elaboração de sequência de passos, que se somam em uma coreografia. Nesse sentido, as histórias (originais ou já existentes) têm sido nossas principais aliadas para a construção de roteiros de cenas, escolhas de músicas, barulhos e objetos. Estabelecidas as cenas, partimos para o estudo dos gestos autorais, buscando como subtextos as linguagens corporais que se mostrarem mais interessantes para 
tal. Em algumas cenas, os gestos são combinados e executados de forma semelhante. Em outras, a cena está sendo contada por gestos singulares de cada criança, embora todos façam parte da "contação" da mesma história. São essas composições que podem resultar, quando for o caso, nos textos dançados que se tornam apresentações ${ }^{15}$.

Mas como nada acontece sem uma intencionalidade pedagógica, no processo de mediação da improvisação e composição infantil, várias intenções podem nortear nossas ações no sentido das discussões que aqui apresentei. Vale ambicionar desconstruir o cantardançar disciplinador junto com as crianças, discutindo, mudando, ou, até mesmo, abolindo do uso de certas letras musicais. Vale apostar na descentralização das estéticas normativas, subvertendo protagonismos, questionando ausências e silenciamentos. Vale investir nos caminhos para um trato mais significativo e autoral com o gesto infantil.

Contudo, cabe-nos o reconhecimento que não enxergamos tudo isso de forma topológica, não temos, sequer, a certeza de agir da melhor forma. Como afirma Veiga-Neto (2016), somos docentes em tempos flexíveis, personagens da sociedade do controle, andarilhos em uma multidão. Trata-se do que Deleuze (2012) chama de espaço háptico, aquele no qual nos deslocamos guiados por um olho-dedo, que vai tateando, experimentando e criando novos caminhos. Nosso ganho reside no fato de que a flexibilidade é atenta, usuária da tática, portanto mais apta à mudança. Nesse percurso, temos a potência das infâncias como nossa parceira, na figura das crianças da escola e no devir-criança que em nós reside.

\section{REFERÊNCIAS}

AGAMBEN, Giorgio. Gosto. Belo Horizonte: Autêntica Editora, 2017.

BRASILEIRO, Lívia Tenório. O conteúdo" dança" em aulas de educação física: temos o que ensinar?. Pensar a prática, v. 6, p. 45-58, 2003.

CORAZZA, Sandra Mara. Infância e Educação: era mais uma vez... quer que conte outra vez? Petrópolis: Vozes, 2002.

DELEUZE, Gilles. Mil platôs: capitalismo e esquizofrenia, vol. 5. São Paulo: Editora 34, 2012.

DELEUZE, Gilles. Crítica e Clínica . São Paulo: Editora 34, 2006.

FOUCAULT, Michel. Vigiar e punir: nascimento da prisão. Petrópolis, Vozes, 1987. 288p.

15 Ao longo da minha pesquisa e prática pedagógica no campo do ensino da dança, tenho encontrado ressonância com o trabalho de Isabel Marques (2001, 2009, 2013). Sua proposta a partir dos conceitos de contexto, subtexto e texto, tem sido um referencial importante na literatura que ancora uma proposta de ensino da dança que tenha compromisso com uma educação crítica, multiculturalista e que dialoga com a filosofia pósestruturalista. 
MALDONADO, Maritza. M Castrillon. Educação infantil: cenário de cartografias do desejo e processo de disciplinarização. Revista de Educação Pública, [S. l.], v. 22, n. 49/1, p. 327-340, 2013. Disponível em:

https://periodicoscientificos.ufmt.br/ojs/index.php/educacaopublica/article/view/918. Acesso em: 14 $\operatorname{mar} 2021$.

MARQUES, Isabel. Notas sobre o corpo e o ensino de dança. Revista Caderno Pedagógico, v. 8, n. 1,2011

MARQUES, Isabel A. Dançando na escola, 4. ed. São Paulo,SP: Cortez, 2007.

MARQUES, Isabel A. Ensino de Dança Hoje: textos e contextos. 2 ed. - São Paulo: Cortez, 1999.

VASCONCELLOS, Tânia. Jogos e Brincadeiras no contexto escolar. Jogos e brincadeiras: desafios e descobertas, 2008. Disponível em: https://periodicos.furg.br/redsis.

VEIGA-NETO, Alfredo. Crise da modernidade e inovações curriculares: da disciplina para o controle. Sísifo, n. 7, p. 141-150/EN 137-146, 2016.

VEIGA-NETO, Alfredo José; DA SILVA, Mozart Linhares. Educação e Estudos Foucaultianos: uma entrevista com Alfredo Veiga-Neto. Reflexão e Ação, v. 29, n. 1, p. 254-263, 2021. 